Nevada

Environmental

Restoration

Project

Corrective Action Plan for

Corrective Action Unit 300:

Surface Release Areas,

Nevada Test Site, Nevada

Controlled Copy No::

Revision: 0

July 2006

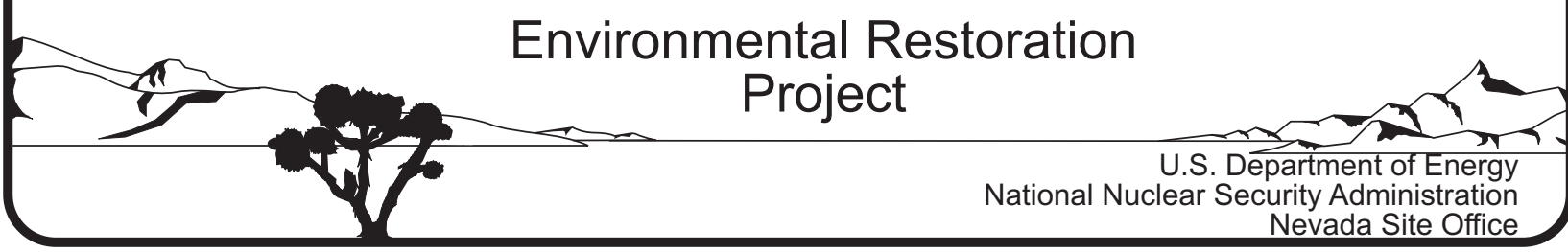




\title{
DISCLAIMER
}

Reference herein to any specific commercial product, process, or service by trade name, trademark, manufacturer, or otherwise, does not necessarily constitute or imply its endorsement, recommendation, or favoring by the United States Government or any agency thereof or its contractors or subcontractors.

This report has been reproduced directly from the best available copy.

Available for sale to the public from:

U.S. Department of Commerce
National Technical Information Service
5285 Port Royal Road
Springfield, VA 22161-0002
Telephone: (800) 553-6847
Fax: (703) 605-6900
E-mail: orders@ntis.gov
Online ordering: http://www.ntis.gov/ordering.htm

Available electronically at http://www.osti.gov/bridge.

Available for a processing fee to the U.S. Department of Energy and its contractors, in paper, from:

\author{
U.S. Department of Energy \\ Office of Scientific and Technical Information \\ P.O. Box 62 \\ Oak Ridge, TN 37831-0062 \\ Telephone: (865) 576-8401 \\ Fax: (865) 576-5728 \\ E-mail: reports@adonis.osti.gov
}




\title{
CORRECTIVE ACTION PLAN FOR CORRECTIVE ACTION UNIT 300: SURFACE RELEASE AREAS NEVADA TEST SITE, NEVADA
}

\author{
U.S. Department of Energy \\ National Nuclear Security Administration \\ Nevada Site Office \\ Las Vegas, Nevada
}

Controlled Copy No.

Revision: 0

July 2006 
THIS PAGE INTENTIONALLY LEFT BLANK 


\section{CORRECTIVE ACTION PLAN FOR CORRECTIVE ACTION UNIT 300: SURFACE RELEASE AREAS NEVADA TEST SITE, NEVADA}

Approved By:

Kevin J. Cabble,

Federal Sub-Project Director

Environmental Restoration Project

Approved By:

Janet L. Appenzeller-Wing,

Federal Project Director

Environmental Restoration Project

Date:

Date: 
THIS PAGE INTENTIONALLY LEFT BLANK 


\section{TABLE OF CONTENTS}

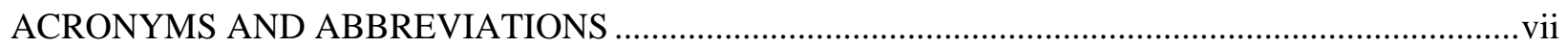

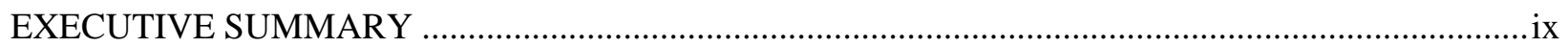

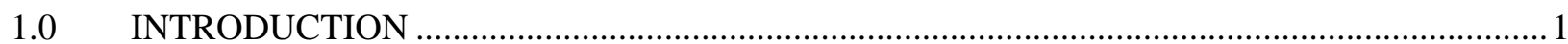

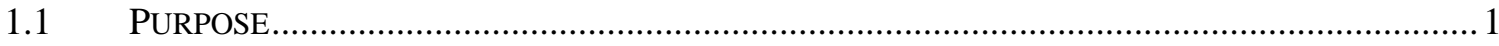

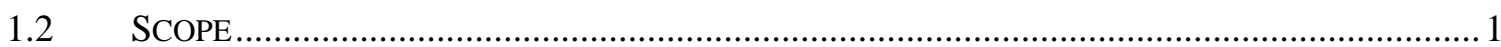

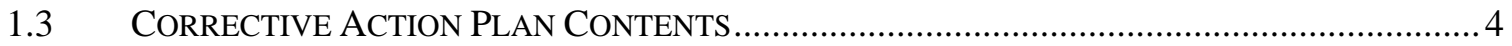

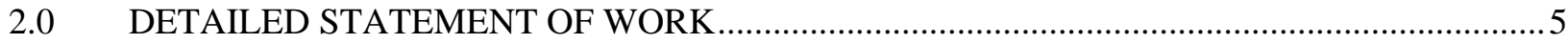

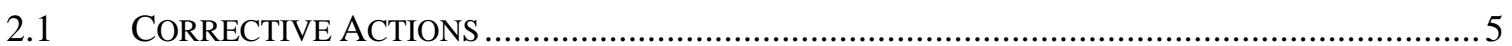

2.1.1 Alternative 1 - No Further Action.................................................................... 5

2.1.2 Alternative 2 - Clean Closure ……….................................................... 7

2.2 CONSTRUCTION QUALITY ASSURANCE / QUALITY CONTROL......................................... 13

2.2.1 Construction Field Sample Collection Activities ................................................ 13

2.2.2 Construction Laboratory/Analytical Data Quality Indicators .............................. 13

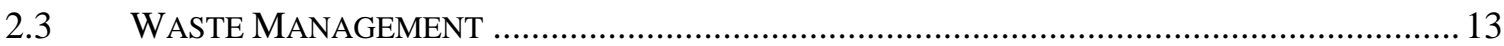

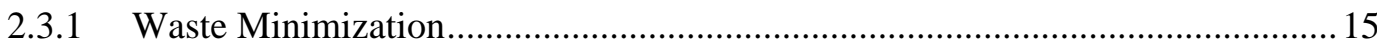

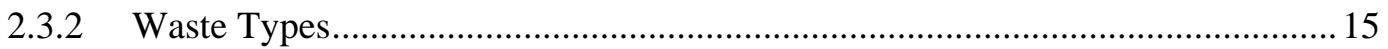

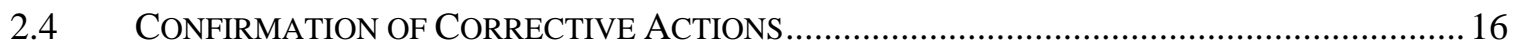

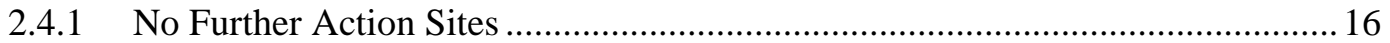

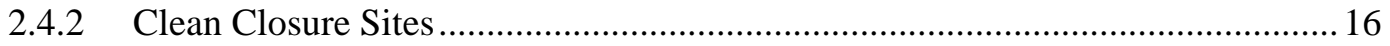

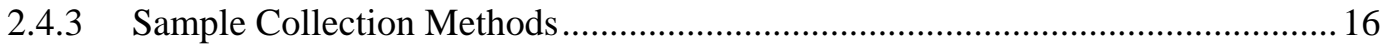

2.4.4 Laboratory/Analytical Data Quality Indicators …............................................ 17

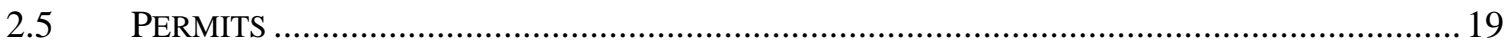

2.5.1 National Environmental Policy Act Checklist ................................................... 19

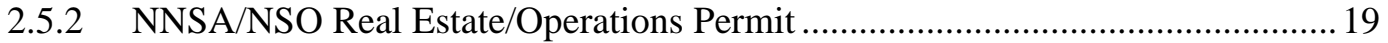

2.5.3 Radiological Work Permit ................................................................................... 19

2.5.4 Utility Clearances, Excavation Permits, and Blind Penetration Permits .............. 19

SCHEDULE

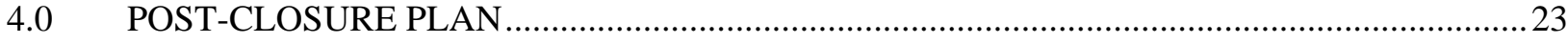

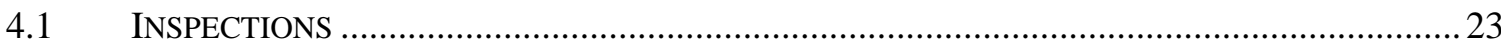

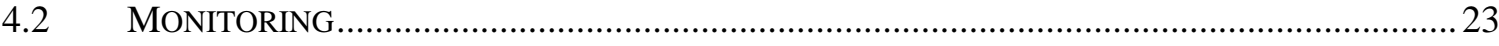

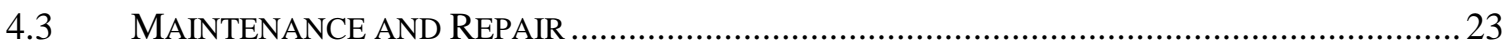

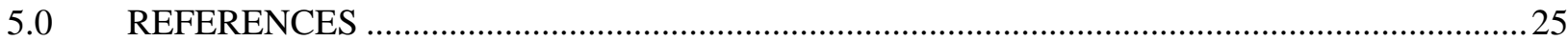

\section{FIGURES}

FiguRE 1. CAU 300 Site Location Map ............................................................................ 2

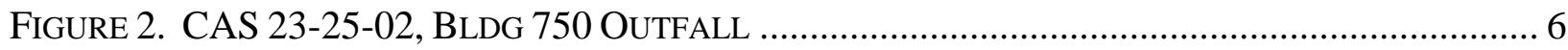

Figure 3. CAS 25-60-01, Bldg 3113A OutFall (Northern Portion)................................. 8

Figure 4. CAS 25-60-01, Bldg 3113A OutFall (SOUTHERn Portion) .................................. 9

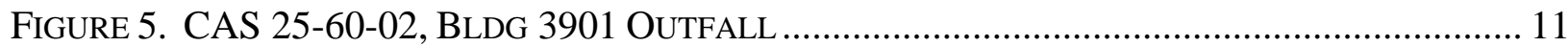

FIGURE 6. CAS 25-62-01, BLDG 3124 CONTAMINATED SOIL................................................ 12

Figure 7. CAS 26-60-01, BLdG 2105 OUTFALl AND DECON PAD.......................................... 14 


\section{APPENDICES}

APPENDIX A.1 Engineering Specifications and Drawings

APPENDIX A.2 Sampling and Analysis Plan

APPENDIX A.3 Project Organization

LIBRARY DISTRIBUTION LIST 


\section{ACRONYMS AND ABBREVIATIONS}

\begin{tabular}{|c|c|}
\hline bgs & below ground surface \\
\hline Bldg & building \\
\hline BMP & best management practice \\
\hline CADD & Corrective Action Decision Document \\
\hline CAIP & Corrective Action Investigation Plan \\
\hline CAP & Corrective Action Plan \\
\hline CAS & Corrective Action Site(s) \\
\hline CAU & Corrective Action Unit(s) \\
\hline $\mathrm{COC}$ & contaminant of concern \\
\hline CR & Closure Report \\
\hline Cs & Cesium \\
\hline DOE & U.S. Department of Energy \\
\hline DOE/NV & U.S. Department of Energy, Nevada Operations Office \\
\hline DQI & Data Quality Indicator(s) \\
\hline DQO & Data Quality Objective(s) \\
\hline DRO & diesel range organics \\
\hline E-MAD & Engine-Maintenance, Assembly, and Disassembly \\
\hline EPA & U.S. Environmental Protection Agency \\
\hline FAL & Final Action Level \\
\hline FFACO & Federal Facility Agreement and Consent Order \\
\hline $\mathrm{ft}$ & foot (feet) \\
\hline in. & inch/inches \\
\hline LLW & low-level waste \\
\hline MBD & Mercury Bypass Ditch \\
\hline$\mu g / \mathrm{kg}$ & micrograms per kilogram \\
\hline $\mathrm{mg} / \mathrm{kg}$ & milligrams per kilogram \\
\hline NAC & Nevada Administrative Code \\
\hline NCRP & National Council on Radiation Protection and Measurements \\
\hline NDEP & Nevada Division of Environmental Protection \\
\hline NEPA & National Environmental Policy Act \\
\hline NNSA/NSO & $\begin{array}{l}\text { U.S. Department of Energy, National Nuclear Security Administration } \\
\text { Nevada Site Office }\end{array}$ \\
\hline NNSA/NV & $\begin{array}{l}\text { U.S. Department of Energy, National Nuclear Security Administration } \\
\text { Nevada Operations Office }\end{array}$ \\
\hline NTS & Nevada Test Site \\
\hline NSTec & National Security Technologies \\
\hline OI & Organization Instruction(s) \\
\hline $\mathrm{OP}$ & Organization Procedure(s) \\
\hline$\% \mathrm{R}$ & percent recovery \\
\hline
\end{tabular}




\section{ACRONYMS AND ABBREVIATIONS (continued)}

$\begin{array}{ll}\text { PCB } & \text { Polychlorinated Biphenyl(s) } \\ \text { pCi/g } & \text { picoCuries per gram } \\ \text { PPE } & \text { personal protective equipment } \\ \text { QA/QC } & \text { Quality Assurance/Quality Control } \\ \text { RCT } & \text { Radiological Control Technician } \\ \text { RPD } & \text { relative percentage difference } \\ \text { REOP } & \text { Real Estate/Operations Permit } \\ \text { RWP } & \text { Radiological Work Permit } \\ \text { SVOC } & \text { Semivolatile Organic Compounds } \\ \text { TPH } & \text { total petroleum hydrocarbons } \\ \text { TCA } & \text { Test Cell A } \\ \text { TTF } & \text { Treatability Test Facility } \\ \text { WGS } & \text { Waste Generator Services } \\ \text { yd }^{3} & \text { cubic yard(s) }\end{array}$




\section{EXECUTIVE SUMMARY}

Corrective Action Unit (CAU) 300, Surface Release Areas, is listed in the Federal Facility Agreement and Consent Order (FFACO) of 1996 (FFACO, 1996). CAU 300 consists of seven Corrective Action Sites (CASs) located in Areas 23, 25, and 26 of the Nevada Test Site, which is located approximately 65 miles northwest of Las Vegas, Nevada. CAU 300 is comprised of the following seven CASs associated with the identified Buildings (Bldg):

- 23-21-03, Bldg 750 Surface Discharge

- 23-25-02, Bldg 750 Outfall

- 23-25-03, Bldg 751 Outfall

- 25-60-01, Bldg 3113A Outfall

- 25-60-02, Bldg 3901 Outfall

- 25-62-01, Bldg 3124 Contaminated Soil

- 26-60-01, Bldg 2105 Outfall and Decon Pad

Site characterization of the CAU 300 CASs was performed in 2004, and the results are presented in the CAU 300 Corrective Action Decision Document (U.S. Department of Energy, National Nuclear Security Administration Nevada Site Office, 2005). Briefly, the results of the site characterization and the scope of work required to implement the recommended closure alternatives include the following:

- CAS 23-21-03, Bldg 750 Surface Discharge, is located in the north end of the Fleet Operations Yard in Area 23. No further action is required for this CAS because no contaminants of concern (COCs) were found above Final Action Levels (FALs).

- CAS 23-25-02, Bldg 750 Outfall, is located southeast of the Fleet Operations Building in Area 23. No COCs were identified above FALs; therefore, no further action is required for this CAS. As a best management practice, approximately 48 feet of piping containing total petroleum hydrocarbons-diesel range organics (TPH-DRO) will be removed and appropriately disposed.

- CAS 23-25-03, Bldg 751 Outfall, is located southeast of Building 751 within the Fleet Operations Yard in Area 23. No COCs were identified above FALs; therefore, no further action is required for this CAS.

- CAS 25-60-01, Bldg 3113A Outfall, is located at the Test Cell A (TCA) facility in Area 25 and is associated with releases from the operations at Building 3113A and from drains around the concrete pad beneath the TCA piping and dewars.

In the northern portion of the site, semivolatile organic compounds (SVOCs), polychlorinated biphenyls (PCBs), and radionuclides were identified at levels above FALs in soil directly below a pipe tie-in location. This portion of the CAS will be clean closed by removing approximately 9.5 cubic yards $\left(\mathrm{yd}^{3}\right)$ of contaminated soil from beneath the pipe tie-in location. All open pipes left in place will be sealed to prevent potential accumulation of media. 


\section{EXECUTIVE SUMMARY (continued)}

In the southern portion of the CAS, SVOCs, TPH-DRO, PCBs, and radionuclides above FALs were identified in soil at the base of the pipe outfall. This portion of the CAS will be clean closed by removing approximately $31 \mathrm{yd}^{3}$ of contaminated soil, and approximately $1.2 \mathrm{yd}^{3}$ of concrete at the outfall location. All contaminated soil and concrete will be appropriately disposed.

- CAS 25-60-02, Bldg 3901 Outfall, is located adjacent to the locomotive maintenance building at the Engine-Maintenance, Assembly, and Disassembly facility in Area 25. The CAS consists of releases from drains within Building 3901 to the outfall piping that discharges to the ground surface adjacent to the railroad tracks west of the building. This CAS will be clean closed by removing approximately $1.3 \mathrm{yd}^{3}$ of TPH-DRO contaminated concrete from the collar surrounding the outfall pipe and sealing any open pipes left in place. All contaminated concrete will be appropriately disposed.

- CAS 25-62-01, Bldg 3124 Contaminated Soil, is located north of the Treatability Test Facility (TTF) Building 3124 at the TCA facility and consists of a surface release from operations at the TTF. This CAS will be clean closed by removing approximately $33 \mathrm{yd}^{3}$ of radioactive contaminated soil from behind the TTF. All contaminated soil will be appropriately disposed.

- CAS 26-60-01, Bldg 2105 Outfall and Decon Pad, is the former location of the Building 2105 Check Station in Area 26. This CAS consists of releases associated with a concrete pad, decontamination (decon) pad, and adjacent ditch located on the north side of the site. This CAS will be clean closed by removing approximately $2.7 \mathrm{yd}^{3}$ of TPH-DRO and radioactive contaminated soil from directly below the concrete outfall. All contaminated soil will be appropriately disposed. 


\subsection{INTRODUCTION}

Corrective Action Unit (CAU) 300, Surface Release Areas, is listed in the Federal Facility Agreement and Consent Order (FFACO) of 1996 (FFACO, 1996). CAU 300 consists of seven Corrective Action Sites (CASs) located in Areas 23, 25, and 26 of the Nevada Test Site (NTS), which is located approximately 65 miles northwest of Las Vegas, Nevada (Figure 1). CAU 300 is comprised of the following seven CASs associated with the identified Buildings (Bldg):

- 23-21-03, Bldg 750 Surface Discharge

- 23-25-02, Bldg 750 Outfall

- 23-25-03, Bldg 751 Outfall

- 25-60-01, Bldg 3113A Outfall

- 25-60-02, Bldg 3901 Outfall

- 25-62-01, Bldg 3124 Contaminated Soil

- 26-60-01, Bldg 2105 Outfall and Decon Pad

Details of the site history and site characterization results for CAU 300 are provided in the approved Corrective Action Investigation Plan (CAIP) (U.S. Department of Energy, National Nuclear Security Administration Nevada Site Office [NNSA/NSO], 2004) and the approved Corrective Action Decision Document (CADD) (NNSA/NSO, 2005).

\subsection{Purpose}

The purpose of this Corrective Action Plan (CAP) is to provide the detailed scope of work required to implement the recommended corrective actions as specified in the approved CAU 300 CADD (NNSA/NSO, 2005).

\subsection{SCOPE}

The results of the CAU 300 site characterization and the scope of work required to implement the recommended corrective actions as stated in the approved CADD (NNSA/NSO, 2005) are briefly summarized below.

CAS 23-21-03, Bldg 750 Surface Discharge, is located in the north end of the Fleet Operations Yard in Area 23 and consists of suspected impacted soils within the Mercury Bypass Ditch (MBD) and the shallow discharge drainage at the western edge of the Building 750 parking lot. Results of the characterization reported no contaminants of concern (COCs) above Final Action Levels (FALs). No further action is required for this CAS.

CAS 23-25-02, Bldg 750 Outfall, is located southeast of the Fleet Operations Building in Area 23. The site consists of subsurface piping starting at the southeast corner of the building and discharges at an outfall into the MBD. The outfall was constructed for the discharge of liquids from the drains associated with the Building 750 steam cleaning pad. Total petroleum hydrocarbons-diesel range organics (TPH-DRO) were detected in the soil at concentrations above the FAL. All TPH-DRO contaminated soil was removed during the site investigation 


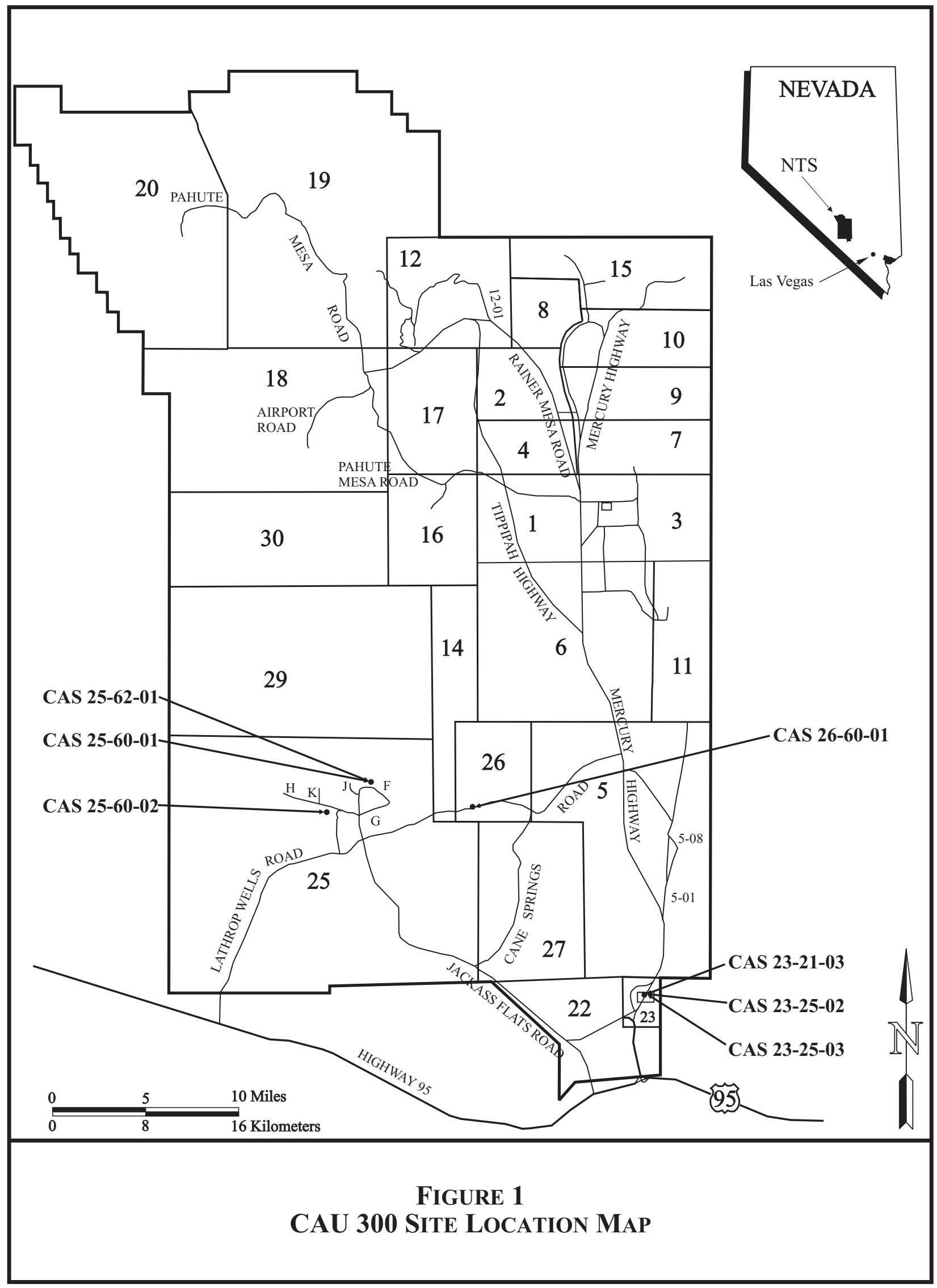


and no further action is required for this CAS (NNSA/NSO, 2005). As a best management practice (BMP), approximately 48 feet $(\mathrm{ft})$ of piping material containing TPH-DRO will be removed and disposed appropriately.

CAS 23-25-03, Bldg 751 Outfall, is located southeast of Building 751 within the Fleet Operations Yard in Area 23. The CAS consists of an outfall that is associated with the drains from the former steam cleaning pad at the Building 751 and leads into the MBD. No COCs were identified above the FALs (NNSA/NSO, 2005) therefore; no further action is required at this CAS.

CAS 25-60-01, Bldg 3113A Outfall, is located at the former Test Cell A (TCA) facility in Area 25 and consists of releases associated with the operations of Building 3113A and from drains around the concrete pad beneath the TCA piping and dewars. In the northern portion of the CAS, semivolatile organic compounds (SVOCs), polychlorinated biphenyls (PCBs), and gamma-emitting radionuclides were identified in soil directly below a pipe tie-in location at concentrations greater than the FALs. In the southern portion of the CAS, SVOCs, TPH-DRO, PCBs, and gamma-emitting radionuclides were identified in the soil at the base of the pipe outfall at concentrations greater than the FALs.

This CAS will be clean closed by removing approximately 9.5 cubic yards $\left(\mathrm{yd}^{3}\right)$ of contaminated soil from beneath the pipe tie-in from the northern potion of the CAS. From the southern portion of the CAS, approximately $31 \mathrm{yd}^{3}$ of contaminated soil and $1.2 \mathrm{yd}^{3}$ of contaminated concrete will be removed from the pipe outfall location. All open pipes left in place will be sealed and all excavations will be backfilled with native material. All contaminated soil and concrete waste will be appropriately disposed.

CAS 25-60-02, Bldg 3901 Outfall, is located adjacent to the locomotive maintenance building at the Engine-Maintenance, Assembly, and Disassembly (E-MAD) facility in Area 25. The CAS consists of releases to the drains within Building 3901 to the outfall piping that discharges to the ground surface adjacent to the railroad tracks to the west. This CAS will be clean closed by removing TPH-DRO contaminated concrete from the base of the pipe outfall. All open pipes left in place will be sealed and all excavations backfilled with native material. Contaminated concrete waste will be appropriately disposed.

CAS 25-62-01, Bldg 3124 Contaminated Soil, is located immediately north of the Treatability Test Facility (TTF) Building 3124 at the TCA facility. The CAS consists of a surface release from operations at the TTF. This CAS will be clean closed by removing approximately $33 \mathrm{yd}^{3}$ of radioactive contaminated soil from behind the TTF. All excavations will be backfilled with native material and all contaminated soil will be appropriately disposed.

CAS 26-60-01, Bldg 2105 Outfall and Decon Pad, is the former location of Building 2105 Check Station in Area 26. This CAS consists of releases associated from a concrete pad, decontamination pad, and adjacent ditch located on the north side of the site. This CAS will be clean closed by removing $3 \mathrm{yd}^{3}$ of TPH-DRO and radioactive contaminated soil from directly below the concrete outfall. All excavations will be backfilled with native material and all contaminated soil will be appropriately disposed. 


\subsection{Corrective Action Plan Contents}

This CAP is comprised of the following sections and appendices:

- Section $1.0 \quad$ Introduction

- Section 2.0 Detailed Statement of Work

- Section $3.0 \quad$ Schedule

- Section 4.0 Post-Closure Plan

- Section 5.0 References

- Appendix A.1 Engineering Specifications and Drawings

- Appendix A.2 Sampling and Analysis Plan

- Appendix A.3 Project Organization

- Library Distribution List

Appendix A.1 is included in this CAP as required by the approved FFACO CAP outline, but contains no material because engineering specifications or drawings are not necessary for closure of CAU 300. Similarly, Appendix A.2 is included as required but contains no material, because Sections 2.1.2 and 2.4 provide sufficient details on sampling.

This report was developed using information and guidance from the following documents:

- Federal Facility Agreement and Consent Order (FFACO, 1996)

- Corrective Action Investigation Plan for Corrective Action Unit 300 (NNSA/NSO, 2004)

- Corrective Action Decision Document for Corrective Action Unit 300 (NNSA/NSO, 2005) 


\subsection{DETAILED STATEMENT OF WORK}

Three corrective action alternatives for CAU 300 were evaluated and identified in the CADD (NNSA/NSO, 2005).

Alternative 1 - No Further Action

Alternative 2 - Clean Closure

Alternative 3 - Close in Place with Administrative Controls

The approved corrective actions for the CAU 300 CASs include:

- CAS 23-21-03, No Further Action

- CAS 23-25-02, No Further Action

- CAS 23-25-03, No Further Action

- CAS 25-60-01, Clean Closure

- CAS 25-60-02, Clean Closure

- CAS 25-62-01, Clean Closure

- CAS 26-60-01, Clean Closure

\subsection{CORRECTIVE ACTIONS}

The corrective action alternatives for CAU 300 are identified in the CADD (NNSA/NSO, 2005) and were approved by the Nevada Division of Environmental Protection (NDEP). The objective of the corrective actions is to prevent or mitigate adverse environmental impacts due to exposure and migration of surface and subsurface waste. The corrective actions for CAU 300 are identified below.

\subsubsection{Alternative 1 - No Further Action}

No Further Action is the approved corrective action for the following CASs.

CAS 23-21-03, Bldg 750 Surface Discharge. No COCs were identified at this CAS during site characterization; therefore, no further actions are required for site closure.

CAS 23-25-02, Bldg 750 Outfall. No COCs were identified during site characterization. As a BMP, a section of approximately $48 \mathrm{ft}$ of the piping containing TPH-DRO will be removed and disposed of appropriately. Any open ends of pipe remaining in place will be sealed and the excavation backfilled with native material (Figure 2).

CAS 23-25-03, Bldg 751 Outfall. No COCs were identified at this CAS during site characterization; therefore, no further actions are required for site closure. 


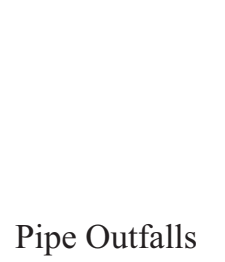

to Ditch

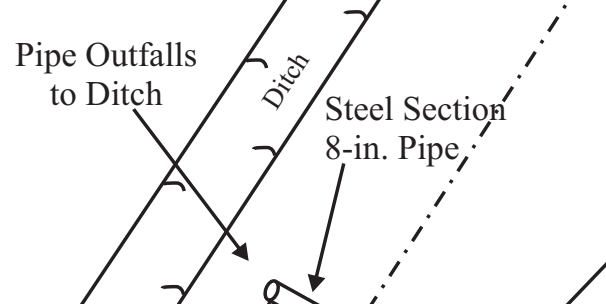

7.
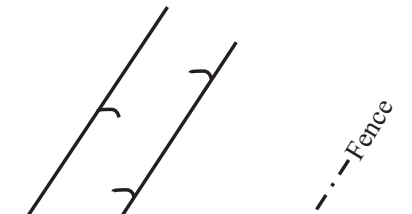

Cast Iron Section 8-in. Pipe

3.5-ft Gap

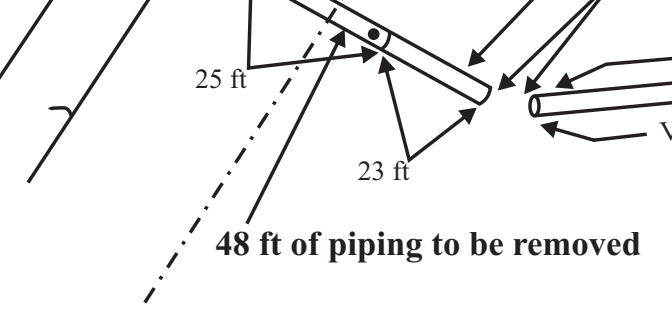

Vitrified Clay Pipe (260 ftof 6-in. Pipe)

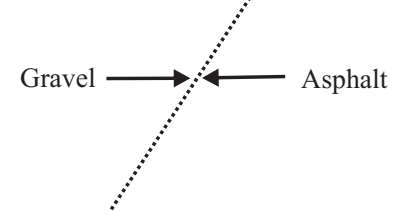

\section{$\underline{\text { LEGEND }}$}

○ Drain

$\longleftarrow$ Subsurface Pipe

-.-.- Fence

- Characterization Sample Above Action Limit

Not to Scale

Source: CAU 300 CADD (NNSA/NSO, 2005)

FIGURE 2

CAS 23-25-02, BLDG 750 OUTFALL
Parking Lot

Building 750

Grouted

Location

Source Drain

Open to the Lin
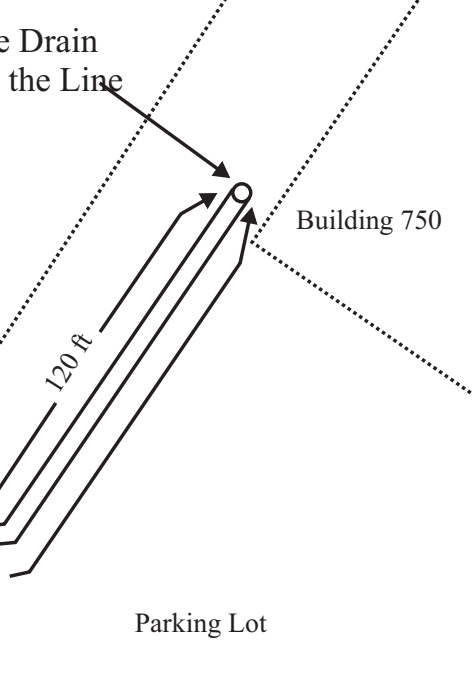


\subsubsection{Alternative 2 - Clean Closure}

Clean Closure is the approved corrective action for the following CASs.

CAS 25-60-01, Bldg 3113A Outfall. CAS 25-60-01 consists of releases associated with the operation of Building 3113A and from drains around the concrete pad beneath the former TCA piping and dewars. The CAS contains COCs above FALs in soil.

Northern Portion: SVOCs, PCBs, and gamma-emitting radionuclides were identified above the FALs directly below a tie-in location identified during the video survey. Characterization results for soil in the 1.5 - $2 \mathrm{ft}$ below ground surface (bgs) showed cesium (Cs)-137 at 15.7 picoCuries per gram (pCi/g), benzo(a)pyrene at 520 micrograms per kilogram ( $\mu \mathrm{g} / \mathrm{kg}$ ) and Aroclor-1260 at $1,100 \mu \mathrm{g} / \mathrm{kg}$. The current FAL for Cs-127 as agreed to by NDEP is $12.2 \mathrm{pCi} / \mathrm{g}$ based on a 25 millirem per year dose (NNSA/NSO, 2006, and National Council on Radiation Protection and Measurements [NCRP], 1999). The criteria for clean closure are the current FALs; the 25 millirem per year dose for radiological COCs, and the EPA Region IX preliminary remediation goals for chemical COCs (NCRP, 1999 and EPA, 2004).

The northern portion of the CAS will be clean closed by removing approximately $9.5 \mathrm{yd}^{3}$ (8 $\times 8 \times 4 \mathrm{ft}$ ) of contaminated soil from beneath the pipe tie-in location (Figure 3). After the estimated volume of soil has been removed, a minimum of five soil verification samples will be collected (four from the sidewalls and one from the base of the excavation). Samples will be analyzed for SVOCs, PCBs, and gamma-emitting radionuclides to verify that no COCs remain on site above action levels. Contaminated soil will be containerized and managed appropriately. Based on the reported levels of COCs in the CADD, the soil will be disposed of onsite (NNSA/NSO, 2005). All open pipes left in place that have potential to accumulate debirs will be sealed. All excavated areas will be backfilled with NTS native fill from a clean borrow source and graded to the approximate surrounding grade.

Southern Portion: The SVOCs, TPH-DRO, PCBs, and gamma-emitting radionuclides were identified above the FALs in soil at the base of the pipe outfall and down gradient from the outfall (Figure 4). Characterization results for the soil found a maximum concentration of Cs-137 of $38.8 \mathrm{pCi} / \mathrm{g}(0-2.5 \mathrm{ft}$ bgs), benzo(a)pyrene at $540 \mu \mathrm{g} / \mathrm{kg}(0.5-1.5 \mathrm{ft}$ bgs), Aroclor-1260 at $15,000 \mu \mathrm{g} / \mathrm{kg}(0-4.5 \mathrm{ft}$ bgs), and TPH-DRO at 300 milligrams per kilogram $(\mathrm{mg} / \mathrm{kg})$ (0-1.5 ft bgs).

This portion of the CAS will be clean closed by removing approximately $31 \mathrm{yd}^{3}$ of contaminated soil from two locations (Figure 4).

- $\quad$ Base of the outfall: $18.5 \mathrm{yd}^{3}(10 \times 10 \times 5 \mathrm{ft})$

- Down gradient of outfall: $12.5 \mathrm{yd}^{3}(17 \times 10 \times 2 \mathrm{ft})$

During soil removal, a Radiological Control Technician (RCT) will survey the soil to determine radioactivity levels. After the estimated volume of soil has been removed from each area, field 


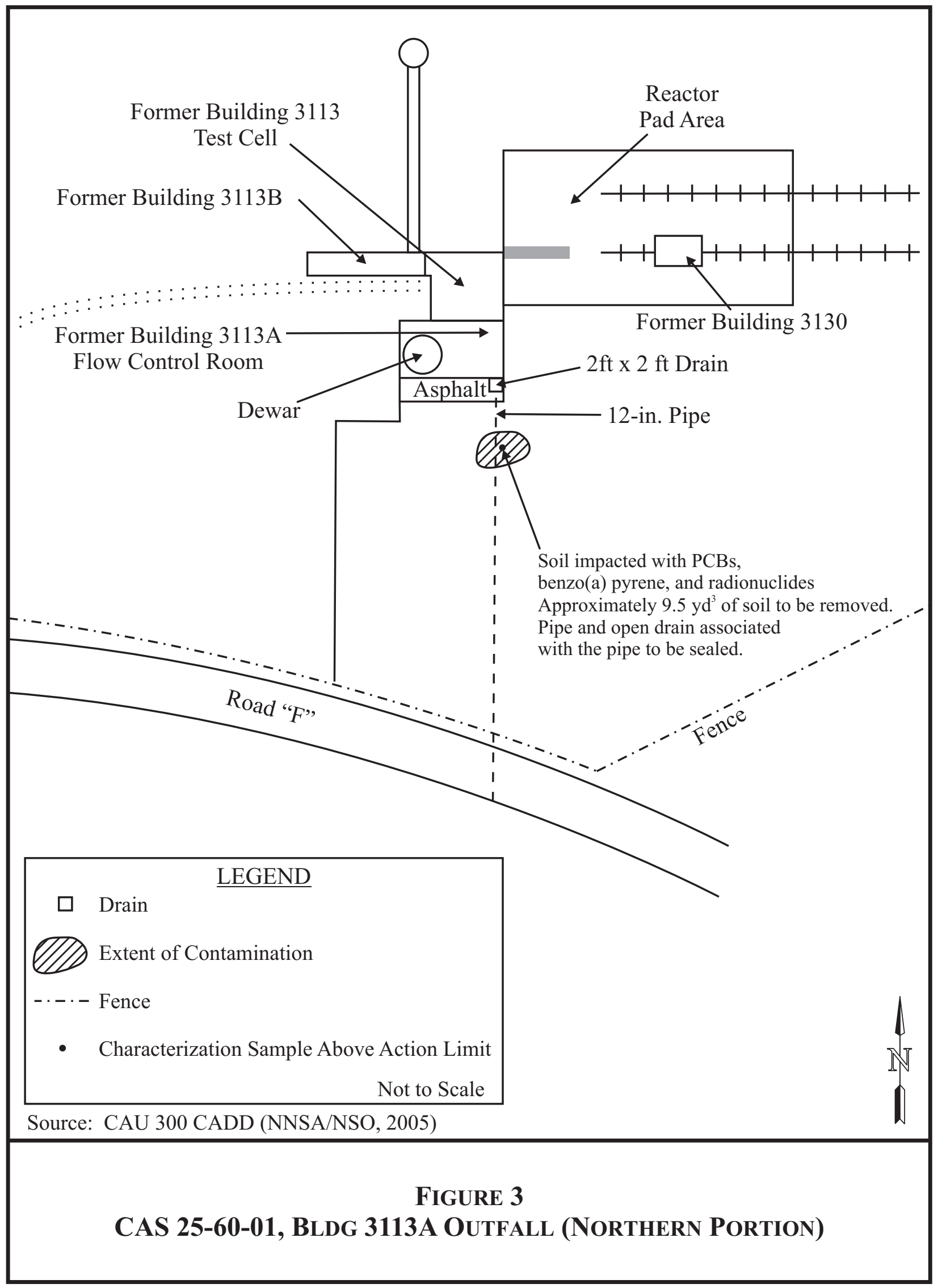




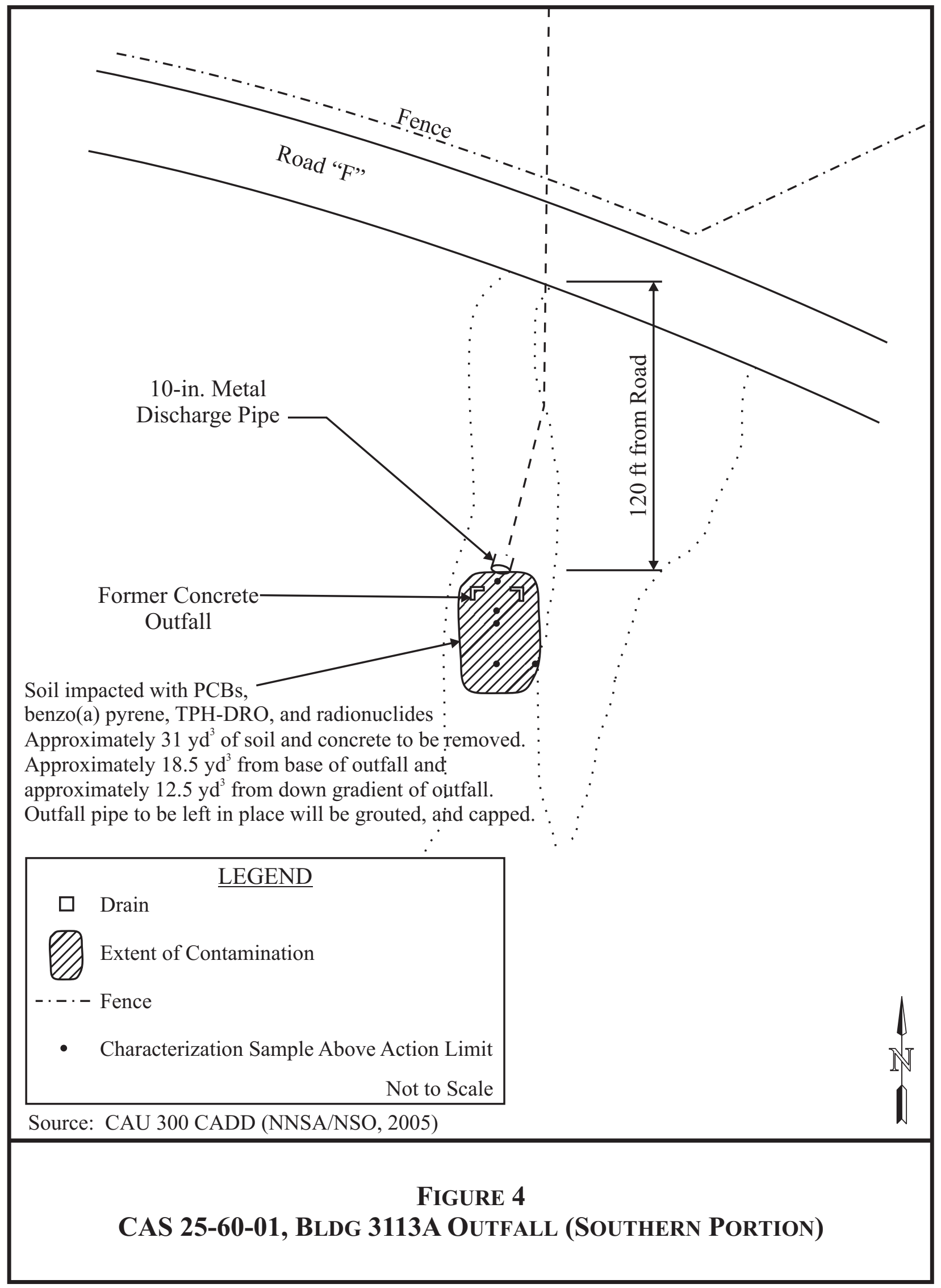


screening for TPH-DRO will be performed using a PetroFLAG ${ }^{\circledR}$ kit or equivalent. Once field screening indicates that TPH-DRO is less than $75 \mathrm{mg} / \mathrm{kg}$, a minimum of five soil verification samples will be collected from the sidewalls and base of each excavation. Samples will be analyzed for PCBs, SVOCs, TPH-DRO, and gamma-emitting radionuclides to verify that the remaining soil is below the action levels. Additionally, approximately $1.2 \mathrm{yd}^{3}$ of concrete will be removed from the base of outfall $(4 \times 4 \times 2 \mathrm{ft})$. The debris will be radiologically screened and transported to an appropriate onsite landfill for disposal. The outfall pipe will be left in place, grouted, and capped.

After analytical results verify no COCs remain on site above action levels, all excavated areas will be backfilled with native fill from a clean borrow source and graded to the approximate surrounding grade. Contaminated soil will be containerized and managed appropriately. Based on reported levels of COCs in the CADD, the soil and concrete will be disposed of onsite.

CAS 25-60-02, Bldg 3901 Outfall. CAS 03-59-02 is located adjacent to the locomotive maintenance building at E-MAD in Area 25. The CAS consists of releases to the drains within Building 3901 to the outfall piping that discharges to the ground surface adjacent to the railroad tracks to the west. TPH-DRO was found in the sample collected from the concrete at a concentration of 1,200 mg/kg, which exceeds the action level of $100 \mathrm{mg} / \mathrm{kg}$ (Figure 5) (Nevada Administrative Code [NAC], 2003). Approximately $1.3 \mathrm{yd}^{3}$ (3 x 5.5 x $2 \mathrm{ft}$ ) of TPH-DRO impacted concrete will be removed from beneath the outfall. After removal of TPH-DRO impacted concrete, field screening for TPH-DRO will be performed using a PetroFLAG ${ }^{\circledR}$ kit or equivalent. Once TPH-DRO field screening indicates that levels remaining on site are less than $75 \mathrm{mg} / \mathrm{kg}$, verification samples will be collected. A minimum of five verification soil samples will be collected from the sidewalls and base of the excavation and analyzed for TPH-DRO. After analytical results verify that soils are clean of TPH-DRO, the excavation will be backfilled with native fill and graded to the approximate surrounding grade. The outfall pipe will remain in place and all openings will be sealed. The concrete debris will be radiologically screened and disposed in an appropriate disposal facility.

CAS 25-62-01, Bldg 3124 Contaminated Soil. CAS 25-62-01 is located on the north of the TTF Building 3124 at the TCA facility. The CAS consists of a surface release from operations at the TTF. Characterization results for soil samples indicate that Cs-137 concentrations range from 8.1-79.1 pCi/g; above the FAL (NCRP, 1999).

This CAS will be clean closed by removing approximately $33 \mathrm{yd}^{3}$ (33 x 27 x $1 \mathrm{ft}$ ) of contaminated soil from the surface release immediately north behind TTF (Figure 6). During soil removal, an RCT will survey the soil to determine radioactivity levels. After the estimated volume of soil has been removed, a minimum of seven soil verification samples will be collected from the base of the excavation. Samples will be analyzed for gamma-emitting radionuclides to verify that soil remaining on site is below action levels. Contaminated soil will be containerized and managed appropriately. Based on process knowledge for the TTF and the CAS, and on reported levels of COCs in the CADD (NNSA/NSO, 2005), the waste will be managed as Low Level Waste while it is characterized for disposal. Waste characterization samples will be collected and analyzed for gamma emitting radionuclides to determine how the waste will be disposed. 


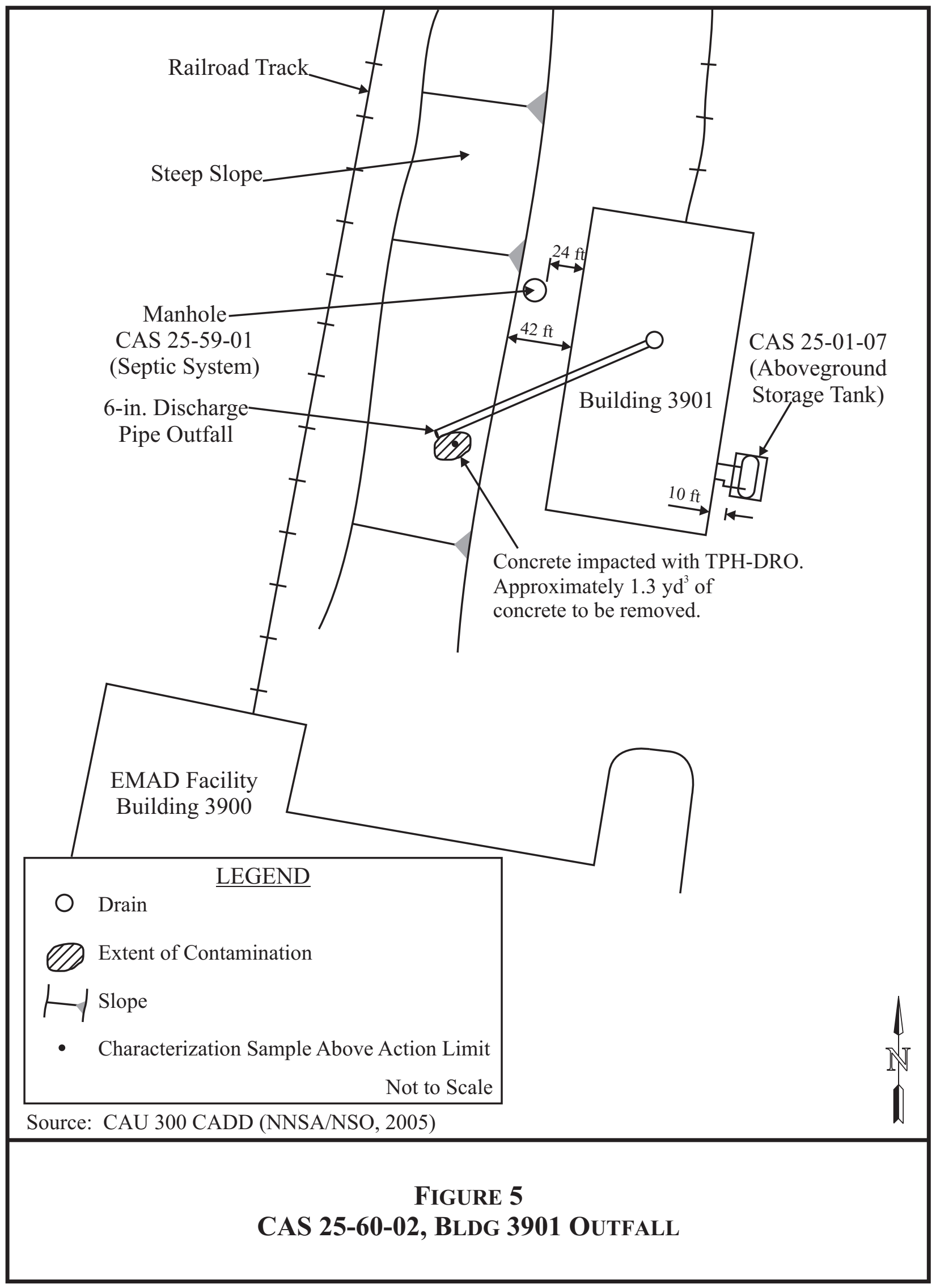


Soil impacted with Cesium-137.

Approximately $33 \mathrm{yd}^{3}$ of soil to be removed.

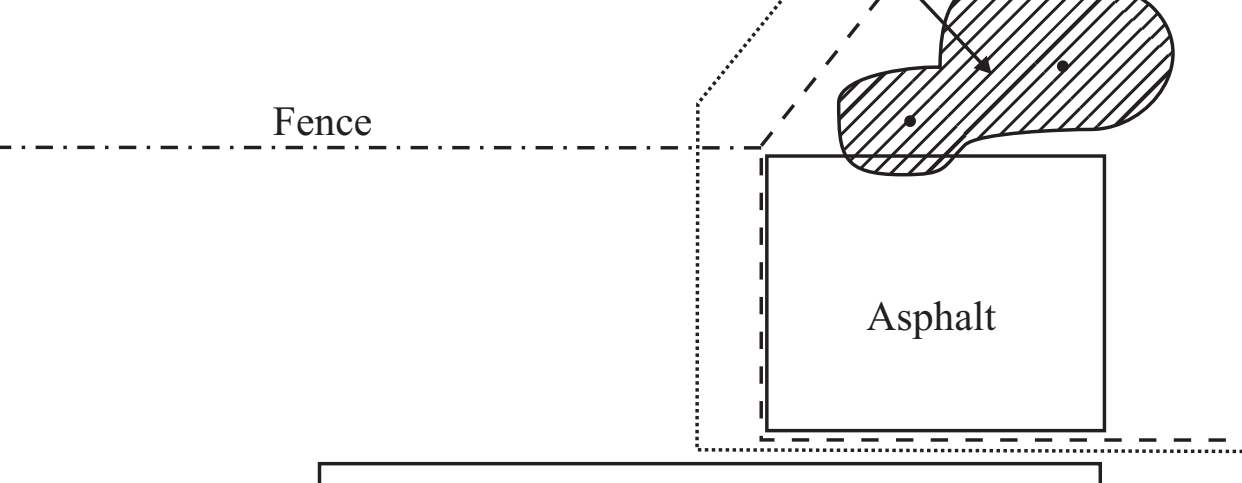

TREATABILITY TEST FACILITY Building 3124

\section{LEGEND}

CAS 25-62-01 Footprint

Extent of Contamination

- - - Yellow Rope - Posted Contamination Area and Radioactive Materials Area

-.-.- Fence

- Characterization Sample Above Action bimit

Source: CAU 300 CADD (NNSA/NSO, 2005)

FIGURE 6

CAS 25-62-01, BLDG 3124 CONTAMINATED SoIL 
samples. The contaminated soil will be appropriately disposed. The excavation will be backfilled with native fill and graded to the approximate surrounding grade.

CAS 26-60-01, Bldg 2105 Outfall and Decon Pad. CAS 26-60-01 is the former location of the Building 2105 Check Station in Area 26. This CAS consists of releases associated with a concrete pad, decontamination pad, and adjacent ditch located on the north side of the site. Characterization results for soil in the $0-1.5 \mathrm{ft}$ bgs identified Cs-137 and TPH-DRO exceeding FALs (Figure 7) (NNSA/NSO, 2005).

Approximately $2.7 \mathrm{yd}^{3}$ of soil will be removed from an area measuring 5 x 5 x $3 \mathrm{ft}$ (Figure 7). During soil removal, an RCT will survey the soil to determine radioactivity levels. After the estimated volume of soil has been removed, field screening for TPH-DRO will be performed using a PetroFLAG ${ }^{\circledR}$ kit or equivalent. Once field screening indicates that TPH-DRO levels are less than $75 \mathrm{mg} / \mathrm{kg}$, a minimum of four soil verification samples will be collected from the sidewalls and base of the excavation. Samples will be analyzed for TPH-DRO and gamma-emitting radionuclides to verify that no COCs remain on site above action levels. Once analytical results verify the site is clean of COCs, the excavation will be backfilled with native fill and graded to the approximate surrounding grade. Contaminated soil will be placed in appropriate containers. Based on characterization results presented in the CADD (NNSA/NSO, 2005), the waste will be disposed of as hydrocarbon waste in the NST Area 6 Hydrocarbon landfill.

\subsection{CONSTRUCtion Quality Assurance / QuAlity CONTROL}

Construction activities are limited to excavation, backfilling, and removal of piping. No engineered structures will be constructed as part of site closure. Therefore, a construction quality assurance/quality control (QA/QC) plan is not required.

\subsubsection{Construction Field Sample Collection Activities}

Construction field samples are not necessary for the closure of the CASs listed in this CAP, although field sample collection activities and radiological surveys will be conducted to verify that clean up criteria have been met for CAS 25-60-01, CAS 25-60-02, CAS 25-62-01, and CAS 26-60-01. Field sample collection activities are addressed in Sections 2.1.2 and 2.4.

\subsubsection{Construction Laboratory/Analytical Data Quality Indicators}

CAU 300 closure activities are limited to soil removal, backfilling, and removal of piping. Therefore, a construction QA/QC plan is not required, and construction Data Quality Indicators (DQI) are not applicable. To ensure that backfill material remains consistent, all fill will be taken from an approved borrow source.

\subsection{WASte MANAGEMENT}

All waste streams will be managed and disposed of in accordance with applicable state and federal regulations, U.S. Department of Energy (DOE) Orders, U.S. Department of Transportation regulations, and the contractor's waste management procedures. CAU 300 closure activities are expected to generate sanitary waste/construction debris, low-level waste 


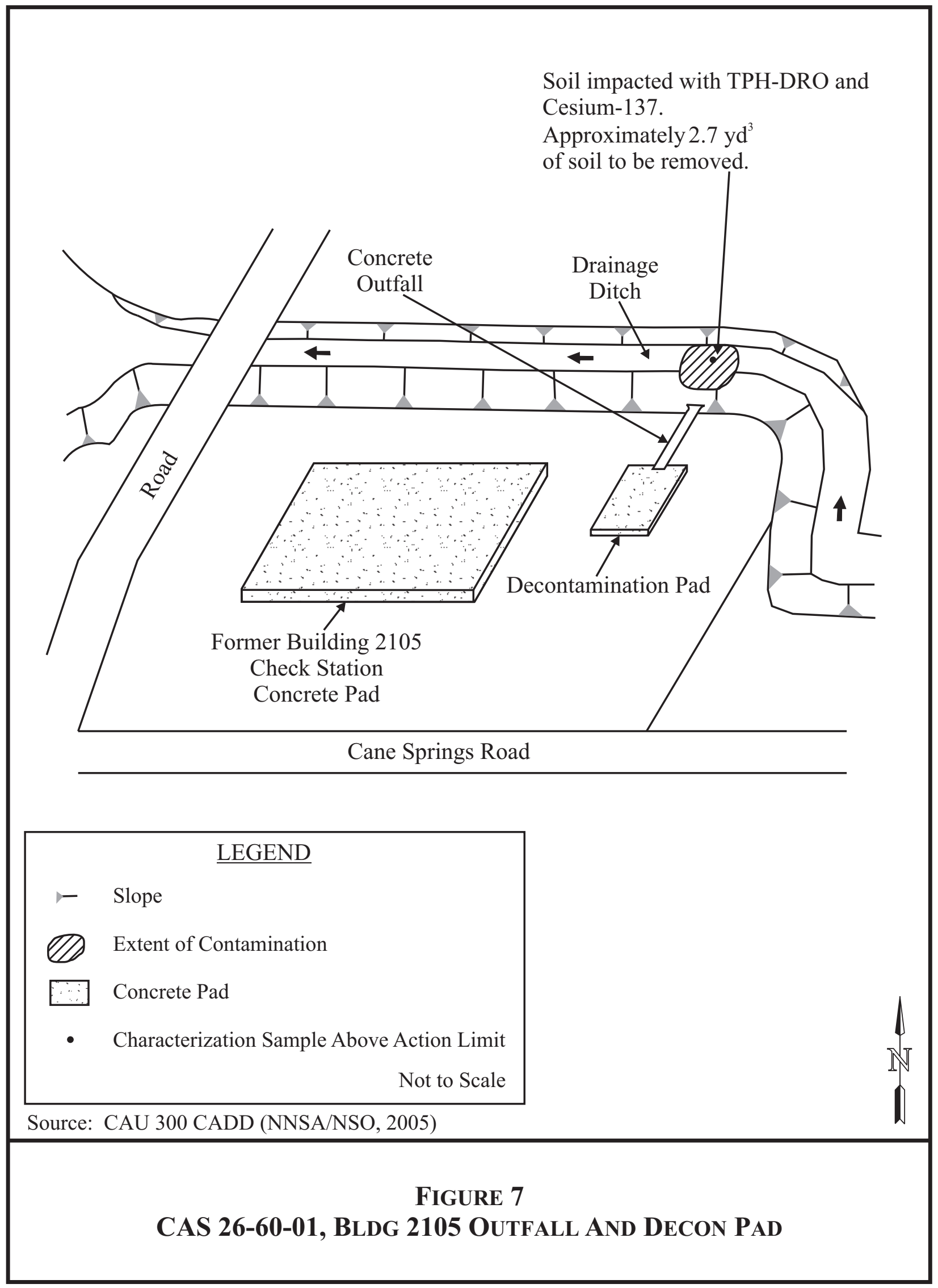


(LLW), and hydrocarbon waste. Waste generated during closure activities will be properly managed and shipped to an onsite or offsite facility. Confirmation of waste disposal or transfer to NSTec WGS for management and disposal will be included in the CAU 300 Closure Report (CR).

\subsubsection{Waste Minimization}

All work activities that generate waste will strive to minimize waste. Special care will be given to properly characterize and segregate waste streams to avoid the generation of additional waste.

\subsubsection{Waste Types}

\section{Sanitary Waste}

Sanitary waste (e.g., non-impacted personal protective equipment [PPE] and general trash) and construction debris (e.g., wood, concrete block, metal, plastic) removed from the site will be radiologically screened for free release (U.S. Department of Energy, Nevada Operations Office [DOE/NV], 2004) and disposed as sanitary waste in an onsite permitted landfill.

\section{Hydrocarbon Waste}

All hydrocarbon contaminated waste will be analyzed for gamma-emitting radionuclides by either the In-Situ Object Counting System or laboratory analysis, in order to satisfy the landfill disposal restrictions. Upon receipt of the analytical results, the waste will be properly characterized and disposed. Any waste meeting the land disposal criteria as specified in the landfill permit will be disposed in the Area 6 Hydrocarbon Landfill. Hydrocarbon waste not meeting the landfill disposal criteria will be stored in a waste accumulation area until a disposal path is finalized.

\section{Low-Level Waste}

Closure activities will potentially generate LLW. The waste will be characterized by process knowledge, laboratory analysis, and/or radiological screening; and a profile for disposal will be prepared. All LLW will be properly characterized by WGS. All LLW shall be managed and disposed in accordance with approved Organization Procedure (OP) OP-2151.304, "Radioactive Waste Tracking, Handling, and Management at the Nevada Test Site” (NSTec, 2004a), and all applicable state and federal regulations. All LLW will be packaged in the presence of a Waste Certification Official and WGS personnel according to OP-2151.304 (NSTec, 2004a). LLW will be stored in a radioactive materials area until transport to an appropriate disposal facility can be arranged.

\section{Decontamination Waste}

All radiologically-impacted equipment will be surveyed prior to release from an exclusion zone. Any equipment that becomes contaminated during closure activities will be decontaminated on site. Dry decontamination will be the preferred method. For larger pieces of equipment that cannot be effectively decontaminated using dry decontamination techniques, wet decontamination techniques will be used. All decontamination rinsate will be managed appropriately in accordance with all applicable regulations, and once characterized, properly disposed. 


\section{Personal Protective Equipment}

All PPE that becomes contaminated during closure activities shall be disposed with the appropriate waste stream. All wastes generated during closure activities will be properly disposed in either onsite landfills or at a permitted offsite treatment, storage, and disposal facility.

\subsection{CONFIRMATION OF CORRECTIVE ACTIONS}

Accurate and defensible analytical data will be collected to characterize waste and verify that the closure objectives outlined in this CAP are met.

\subsubsection{No Further Action Sites}

At three CASs, no COCs were found above FALs. The sites will be closed by taking no further action and BMPs. The final site condition of these three CASs will be verified by visual inspection and photographic documentation included in the final CAU $300 \mathrm{CR}$. These CASs include:

- CAS 23-21-03, Bldg 750 Surface Discharge. No COCs were identified at this CAS.

- CAS 23-25-02, Bldg 750 Outfall. No COCs were identified at this CAS. As a BMP, approximately $48 \mathrm{ft}$ of piping material containing TPH-DRO will be removed as a BMP and disposed appropriately.

- CAS 23-25-03, Bldg 751 Outfall. No COCs were identified at this CAS.

\subsubsection{Clean Closure Sites}

Section 2.1.2 provides information on verification samples required for the following CASs:

- 25-60-01, Bldg 3113A Outfall

- 25-60-02, Bldg 3901 Outfall

- 25-62-01, Bldg 3124 Contaminated Soil

- 26-60-01, Bldg 2105 Outfall and Decon Pad

The site will be considered clean closed after laboratory results verify that verification samples are below the applicable action levels. In addition, removal of materials will be confirmed by visual inspection and photographic documentation of final site conditions.

\subsubsection{Sample Collection Methods}

All samples will be collected by qualified NSTec Environmental Restoration personnel and/or WGS personnel. Samples will be collected by hand, using disposable pre-cleaned or decontaminated sampling equipment (NSTec, 2000a). Samples will be collected either by hand from indicated locations or, if the excavation poses a safety hazard to sampling personnel, from the center of a backhoe bucket of soil collected from indicated locations. Sample collection date, time, and other pertinent information will be logged on a "Chain of Custody Record" form and recoded in a bound project field notebook.

All samples will be collected in clean containers, labeled appropriately, sealed with a tamper-proof seal, bagged, placed on ice in a cooler, and transported to the NSTec 
Environmental Technical Services group under a "Chain of Custody Record” form (NSTec, 2000b). NSTec Environmental Technical Services group will be responsible for sample management and shipment of the samples to an approved offsite laboratory for analysis. Samples will be analyzed by EPA-approved analytical methods at EPA-approved laboratories (EPA, 1996). Sample analysis will include laboratory analysis of QA/QC samples and will follow stringent QA/QC procedures (EPA, 1996). Sample analysis for radionuclides will be performed in accordance with Environmental Measurements Laboratory Procedures Manuals (DOE, 1997).

All samples will be labeled with a unique sample identification number using the CAS number followed by the sample number (e.g., 256001-V1). Waste characterization samples will be named by using the CAS number followed by the sample number (e.g., 256001-WC1).

One set of QA/QC samples will be collected for every 20 environmental samples or one per sample batch. QA/QC samples will include blind duplicates, matrix spike/matrix spike duplicates, and equipment rinsate samples. All blind duplicates will be labeled with a unique sample number.

\subsubsection{Laboratory/Analytical Data Quality Indicators}

Data Quality Objectives (DQO) are qualitative and quantitative statements that specify the quality of the data required to support closure of a site. The DQO for the CAU 300 site investigation were defined in the CAIP (NNSA/NSO, 2004) using the Seven Step DQO Process developed by the EPA (EPA, 2000). Three Conceptual Site Models for the CAU 300 CASs were defined in the CAIP (NNSA/NSO, 2004), and these models were reconciled with the results of the site investigation in the CADD (NNSA/NSO, 2005). (See Appendix A of the CADD.)

Sample analytical results will be generated during closure activities for CAS 25-60-01 (Bldg 3113A Outfall), CAS 25-60-02 (Bldg 3901 Outfall), CAS 25-62-01 (Bldg 3124 Contaminated Soil), and CAS 26-60-01 (Bldg 2105 Outfall and Decon Pad). These CASs will be clean closed and will require the collection and analysis of verification soil samples. All laboratory data generated during closure activities will be reviewed by project personnel to ensure the data are usable and complete according to the CAU 300 DQO. In addition, as specified in the Industrial Sites Quality Assurance Project Plan (U.S. Department of Energy, National Nuclear Security Administration Nevada Operations Office [NNSA/NV], 2002), 100 percent of the final data packages for verification samples will be evaluated at the Tier I and Tier II levels using applicable Organization Instructions (OIs). These include OI-2151.303 (NSTec, 2004b), for validating radiological data, and OI-2154.459 (NSTec, 2003), for validating inorganic chemical data. OI-2154.459 is based on EPA Functional Guidelines (EPA, 2002). Any data determined not to be valid will be identified in the CR. More details on the proposed number and location of the verification samples are given in Section 2.1.2 of this plan.

DQI are qualitative and quantitative statements that specify the data requirements of a project. The DQI include accuracy, precision, comparability, completeness, representativeness, and sensitivity. These DQI are discussed below. 


\section{Precision}

Precision is a measure of agreement among a replicate set of measurements of the same property under similar conditions. This agreement is expressed as the relative percentage difference (RPD) between duplicate measurements (EPA, 1996). Precision applies to parameters sampled and analyzed in duplicate.

One duplicate sample will be collected per set of 20 or fewer verification samples. All duplicate samples will be collected from the same medium and analyzed for the same set of analytes as verification samples. The precision of the analytical results will be assessed by calculating the RPD for a verification sample and its duplicate sample results. An RPD of less than or equal to 30 percent indicates acceptable precision (NNSA/NV, 2002).

\section{Accuracy}

Accuracy is a measure of the closeness of an individual measurement or the average of a number of measurements to the true value. Accuracy includes a combination of random error (precision) and systematic error (bias) components that result from sampling and analytical operations. This closeness is expressed as percent recovery (\%R) (EPA, 1996). Accuracy will be assessed by examining the \%R of laboratory control and spiked samples. A \%R within the range of 70 to 130 percent indicates satisfactory analytical accuracy (NNSA/NV, 2002).

\section{Representativeness}

Representativeness is a qualitative evaluation of measurement system performance. It is the degree to which sample data accurately and precisely represent a characteristic of a population, parameter variations at a sampling point, or an environmental condition (EPA, 1996).

Representativeness will be attained by ensuring that the sample locations, analytical parameters, analytical methods, sampling protocols, and sample handling all meet the project-specific objectives.

\section{Comparability}

Comparability is a qualitative measure that expresses the confidence that one data set can be compared to another. It will be achieved by using standardized field sampling procedures. The same analytical laboratory will perform the same analyses for all samples. Sample results will be reported in standard units to allow for comparison of the data.

\section{Completeness}

Completeness is a quantitative measure of data quality expressed as the percentage of valid data obtained that satisfies the project-specific requirements. Since a limited number of samples will be collected for both waste characterization and verification of closure, 100 percent of the data collected needs to be of acceptable quality to maintain acceptable QA/QC standards.

\section{Sensitivity}

Sensitivity is the capability of a method or instrument to discriminate between measurement responses representing different levels of a variable of interest. This indicator is determined from the value of the standard deviation at the concentration level of interest. It represents the minimum difference of concentration that can be distinguished between two samples with a high degree of confidence. Sensitivity must be sufficient to detect contaminants at or below decision 
levels. Sensitivity will be achieved by analyzing all samples using appropriate EPA-approved analytical laboratories, methods, and instruments.

\subsection{PERMits}

Prior to beginning field closure activities, planning documents and permits will be prepared. These documents will include a Field Management Plan, National Environmental Policy Act (NEPA) Checklist, NNSA/NSO Real Estate/Operations Permit (REOP), Radiological Work Permit (RWP), NSTec Work Packages, excavation permits, and blind penetration permits.

\subsubsection{National Environmental Policy Act Checklist}

A NEPA Checklist will be completed prior to all excavation activities at the site. Excavation activities will follow all applicable federal, state, and local laws, regulations, and permits regarding protection of the environment.

\subsubsection{NNSA/NSO Real Estate/Operations Permit}

A REOP will be obtained prior to beginning closure activities. The permit will establish the NNSA/NSO as the prime authority possessing control of the site.

\subsubsection{Radiological Work Permit}

RWPs will be required for work at any radiologically impacted site when radiological conditions require, as determined by NSTec Health Physics. RWPs will inform workers of the specific PPE necessary to protect them while performing their tasks and identify site-specific controls. The workers will be required to sign the permits and acknowledge their understanding of the requirements before entry into any contamination area, if present. The RWPs will be maintained by the RCT at the entrance to the contamination area. All site workers will be required to be Radiation Worker II trained to perform any work within a radiologically controlled area.

\subsubsection{Utility Clearances, Excavation Permits, and Blind Penetration Permits}

An excavation permit and a blind penetration permit will be obtained prior to beginning any excavation activities. These permits require that a utility clearance be performed. A copy of the permit will be filed on site throughout the duration of the project. 
CAP - CAU 300

Section: Detailed SOW

Revision: 0

Date: July 2006

THIS PAGE INTENTIONALLY LEFT BLANK 


\subsection{SCHEDULE}

All preparation and field activities are scheduled for completion in Fiscal Year 2007. The FFACO deadline for the CR is October 31, 2007. Sufficient flexibility will be incorporated into the field schedule to allow for minor difficulties (e.g., weather, equipment failure). NNSA/NSO shall notify NDEP of any condition or event that may impact the project schedule. 
CAP - CAU 300

Section: Schedule

Revision: 0

Date: July 2006

THIS PAGE INTENTIONALLY LEFT BLANK 


\subsection{POST-CLOSURE PLAN}

The approved corrective action is Alternative 1 - No Further Action for CAS 23-21-03, CAS 23-25-02, and CAS 23-25-03; therefore, no post-closure monitoring is required. For CAS 25-60-01, CAS 25-60-02, CAS 25-62-01, and CAS 26-60-01, the approved corrective action is Alternative 2 - Clean Closure; no post-closure monitoring or site inspections are required.

\subsection{INSPECTIONS}

No post-closure inspection will be required, because all CASs will be clean closed or closed with no further action.

\subsection{MONITORING}

Because no sampling or collection of data will be performed after closure of the CAU, no post-closure monitoring is required for these CASs.

\subsection{MAINTENANCE AND REPAIR}

CAU 300 will be clean closed; therefore, no post-closure maintenance or repairs will be required. 
CAP - CAU 300

Section: Post-Closure Plan

Revision: 0

Date: July 2006

THIS PAGE INTENTIONALLY LEFT BLANK 


\subsection{REFERENCES}

DOE, see U.S. Department of Energy.

DOE/NV, see U.S. Department of Energy/Nevada Operations Office.

EPA, see U.S. Environmental Protection Agency.

FFACO, see Federal Facility Agreement and Consent Order.

Federal Facility Agreement and Consent Order. 1996 (as amended). Agreed to by the State of Nevada, the U.S. Department of Energy, and the U.S. Department of Defense.

NAC, see Nevada Administrative Code.

NCRP, see National Council on Radiation Protection and Measurements.

NDEP, see Nevada Division of Environmental Protection.

NSTec, see National Security Technologies.

NNSA/NSO, see U.S. Department of Energy, National Nuclear Security Administration Nevada Site Office.

NNSA/NV, see U.S. Department of Energy, National Nuclear Security Administration Nevada Operations Office.

National Council on Radiation Protection and Measurements. 1999. Recommended Screening Limits for Contaminated Surface Soil and Review of Factors Relevant to Site-Specific Studies, NCRP Report Number 129, Bethesda, MD.

National Security Technologies. 2000a. “Soil Sampling,” Organization Instruction OI-2152.108, Revision 0. Las Vegas, NV.

National Security Technologies. 2000b. “Sample Chain of Custody,” Organization Instruction OI-2152.100, Revision 0. Las Vegas, NV.

National Security Technologies. 2003. “Inorganic Data Verification and Validation,” Organization Instruction OI-2154.459. Las Vegas, NV.

National Security Technologies. 2004a. “Radiological Waste Tracking, Handling, and Management at the NTS,” Organization Procedure OP-2151.304, Revision 5. Las Vegas, NV.

National Security Technologies. 2004b. "Validation of Radiological and Chemical Laboratory Data,” Organization Instruction OI-2151.303. Las Vegas, NV. 


\section{REFERENCES (continued)}

Nevada Administrative Code. 2003. NAC 445A.2272, “Contamination of Soil: Establishment of Action Level.” Carson City, NV

U.S. Department of Energy. 1997. Environmental Measurements Laboratory Procedures Manual, HASL-300, $28^{\text {th }}$ Ed., Vol. 1. New York, NY.

U.S. Department of Energy, National Nuclear Security Administration Nevada Operations Office. 2002. Industrial Sites Quality Assurance Project Plan, Nevada Test Site, Nevada, Rev. 3, DOE/NV--372. Las Vegas, NV.

U.S. Department of Energy, National Nuclear Security Administration Nevada Site Office. 2004. Corrective Action Investigation Plan for Corrective Action Unit 300: Surface Release Areas, Nevada Test Site, Nevada, DOE/NV-980-Rev. 0, Las Vegas, NV.

U.S. Department of Energy, National Nuclear Security Administration Nevada Site Office. 2005. Corrective Action Decision Document for Corrective Action Unit 300: Surface Release Areas, Nevada Test Site, Nevada, DOE/NV-1039-Rev.0, Las Vegas, NV.

U.S. Department of Energy, National Nuclear Security Administration Nevada Site Office. 2006. Industrial Sites Project Establishment of Final Action Levels, Rev. 0, DOE/NV--1107. Las Vegas, NV.

U.S. Department of Energy, Nevada Operations Office. 2004. NV/YMP Radiological Control Manual, DOE/NV/11718-079, REV. 5, Las Vegas, NV.

U.S. Environmental Protection Agency. 1996. Test Methods for Evaluating Solid Waste Physical/Chemical Methods, SW-846, Third Edition. Washington, D.C.

U.S. Environmental Protection Agency. 2000. Guidance for Data Quality Assessment: Practical Methods for Data Analysis, EPA QA/G-9, EPA/600/R-96/055. Washington, D.C.

U.S. Environmental Protection Agency. 2002. Contract Laboratory Program National Functional Guidelines for Inorganic Data Review, EPA/540/R-94/013. Washington, D.C.

U.S. Environmental Protection Agency. 2004. Region 9 Preliminary Remediation Goals, October, San Francisco, CA. 


\section{APPENDIX A.1}

\section{ENGINEERING SPECIFICATIONS AND DRAWINGS}

NOTE: Engineering specifications and drawings are not required for closure of CAU 300. This appendix is included here as required by the approved Federal Facility Agreement and Consent Order outline for a Corrective Action Plan. 
CAP - CAU 300

Section: Appendix A.1

Revision: 0

Date: July 2006

THIS PAGE INTENTIONALLY LEFT BLANK 


\section{APPENDIX A.2}

\section{SAMPLING AND ANALYSIS PLAN}

NOTE: Sufficient details on the type, number, and location of verification samples to be collected to verify site closure activities have been provided in Sections 2.1.2 and 2.4. This appendix is included here as required by the approved Federal Facility Agreement and Consent Order outline for a Corrective Action Plan. 
CAP - CAU 300

Section: Appendix A.2

Revision: 0

Date: July 2006

THIS PAGE INTENTIONALLY LEFT BLANK 


\section{APPENDIX A.3}

\section{Project Organization}


CAP - CAU 300

Section: Appendix A.3

Revision: 0

Date: July 2006

THIS PAGE INTENTIONALLY LEFT BLANK 


\section{PROJECT ORGANIZATION}

For this project, the U.S. Department of Energy, National Nuclear Security Administration Nevada Site Office (NNSA/NSO) points of contact are as follows:

NNSA/NSO Industrial Sites Federal Sub-Project Director: Kevin Cabble

Telephone Number: (702) 295-5000

NNSA/NSO Task Manager: Sabine Curtis

Telephone Number: (702) 295-0542

The identification of the project Health and Safety Officer and the Quality Assurance Officer can be found in the appropriate plan. However, personnel are subject to change and it is suggested that the appropriate U.S. Department of Energy Project Manager be contacted for further information. The Task Manager will be identified in the Federal Facility Agreement and Consent Order Monthly Activity Report prior to the start of field activities. 
CAP - CAU 300

Section: Appendix A.3

Revision: 0

Date: July 2006

THIS PAGE INTENTIONALLY LEFT BLANK 
CAP - CAU 300

Section: Distribution

Revision: 0

Date: July 2006

\section{LIBRARY DISTRIBUTION LIST}


CAP - CAU 300

Section: Distribution

Revision: 0

Date: July 2006

THIS PAGE INTENTIONALLY LEFT BLANK 


\section{LIBRARY DISTRIBUTION LIST}

U.S. Department of Energy

National Nuclear Security Administration

Nevada Site Office

Technical Library

P.O. Box 98518, M/S 505

Las Vegas, NV 89193-8518

U.S. Department of Energy

Office of Scientific and Technical Information

P.O. Box 62

Oak Ridge, TN 37831-0062

Southern Nevada Public Reading Facility

c/o Nuclear Testing Archive

P.O. Box 98521, M/S 400

Las Vegas, NV 89193-8521

Manager, Northern Nevada FFACO

Public Reading Facility

c/o Nevada State Library \& Archives

100 N Stewart Street

Carson City, NV 89701-4285
1 (Uncontrolled)

1 (Uncontrolled, electronic copy)

1 (Controlled)

1 (Uncontrolled)

1 (Uncontrolled) 
CAP - CAU 300

Section: Distribution

Revision: 0

Date: July 2006

THIS PAGE INTENTIONALLY LEFT BLANK 